\title{
THE
}

$11-13-2013$

\section{Concentrations, Fluxes and Residence Time of PBDEs Across the Tropical Atlantic Ocean}

\author{
Rainer Lohmann \\ University of Rhode Island, rlohmann@uri.edu \\ Jana Klanova \\ Petr Kukucka \\ Shifra Yonis \\ Kevyn Bollinger
}

Follow this and additional works at: https://digitalcommons.uri.edu/gsofacpubs

The University of Rhode Island Faculty have made this article openly available.

Please let us know how Open Access to this research benefits you.

This is a pre-publication author manuscript of the final, published article.

Terms of Use

This article is made available under the terms and conditions applicable towards Open Access

Policy Articles, as set forth in our Terms of Use.

\section{Citation/Publisher Attribution}

Lohmann, R., Klanova, J., Kukucka, P., Yonis, S., \& Bollinger, K. (2013). Concentrations, fluxes and residence time of PBDEs across the tropical Atlantic Ocean. Environmental Science \& Technology, 47(24), p. 13967-75.

Available at: http://dx.doi.org/10.1021/es403494b

This Article is brought to you for free and open access by the Graduate School of Oceanography at DigitalCommons@URI. It has been accepted for inclusion in Graduate School of Oceanography Faculty Publications by an authorized administrator of DigitalCommons@URI. For more information, please contact digitalcommons-group@uri.edu. 


\section{Concentrations, fluxes and residence time of PBDEs across the tropical Atlantic}

\section{Ocean}

\author{
Rainer Lohmann $^{1 *}$, Jana Klanova ${ }^{2}$, Petr Kukucka ${ }^{2}$, Shifra Yonis ${ }^{1}$, Kevyn Bollinger $^{1}$ \\ ${ }^{1}$ Graduate School of Oceanography, University of Rhode Island, South Ferry Road, \\ Narragansett, 02882 Rhode Island, USA
}

${ }^{2}$ Research Centre for Toxic Compounds in the Environment (RECETOX), Faculty of Science, Masaryk University, Kamenice 573/5, 62500 Brno, Czech Republic *mailto:lohmann@gso.uri.edu, Tel:(401) 874-6612, Fax:(401) 874-6811

Little is known about the fate of polybrominated diphenylethers (PBDEs) across the Oceans. Air and water were sampled using both active and passive polyethylene samplers on an EastWest transect across the tropical Atlantic Ocean in 2009, and analyzed for PBDEs. Typical particle-bound concentrations of PBDEs in the surface water were low, at $<1 \mathrm{pg} \mathrm{L}^{-1}$. Truly dissolved concentrations from passive samplers were $\sim 0.5 \mathrm{pg} \mathrm{L}^{-1}$ for BDE 47 and around 0.1 pg $\mathrm{L}^{-1}$ for BDEs 28,99 and 100 (results from active samples were compromised). In the atmosphere, particle-bound BDE 209 dominated overall concentrations (median $1.2 \mathrm{pg} \mathrm{m}^{-3}$ ), followed by BDE $99\left(0.13 \mathrm{pg} \mathrm{m}^{-3}\right)$. Gas-phase concentrations based on passive samplers were 1-8 $\mathrm{pg} \mathrm{m}^{-3}$ for BDE 47 , and $\leq 4 \mathrm{pg} \mathrm{m}^{-3}$ for BDE 99. Net air-water exchange gradients strongly favoured gas-phase deposition of PBDEs into the water. Net gas-phase deposition fluxes ranged from 10s of $\mathrm{pg} \mathrm{m}^{-2}$ day $^{-1}$ for BDEs 28 and 85 to around $1 \mathrm{ng} \mathrm{m}^{-2}$ day $^{-1}$ for BDE 47, 99 and 209. Settling fluxes of particle-bound PBDEs in atmosphere and surface water were around $50 \mathrm{pg} \mathrm{m}^{-2} \mathrm{day}^{-1}$ for BDE 47 , and $<10 \mathrm{pg} \mathrm{m}^{-2}$ day $^{-1}$ for the other congeners. 
26 Oceans have emerged as an important buffer and final sink for a wide range of persistent 27 organic pollutants (POPs). ${ }^{1-4}$ There are four major pathways affecting POPs in the Oceans. The most important pathway for persistent hydrophobic and lipophilic compounds is the biological pump, which moves POPs to depth by partitioning into phytoplankton and settling to depth ${ }^{4,5}$. POPs can also be moved to depth via the subduction of surface water ${ }^{3}$. Another 'physical' pathway is the movement to depth via eddy diffusion, which will be most important for polar compounds which do not sorb strongly to organic carbon in the water column ${ }^{6}$. Lastly, compounds can be prone to degradation, either biodegradation ${ }^{7}$ or by direct and indirect photolysis in the surface water ${ }^{8,9}$. Potential sources of POPs to the Atlantic combine atmospheric deposition and riverine transport from terrestrial sources. In the case of polybrominated diphenylethers (PBDEs), there is the possibility that debromination reactions results in the production of lower brominated congeners in situ ${ }^{10}$. Due to their low vapour pressure, and high lipophilicity, their transport on particles in atmosphere and seawater is likely the dominating process.

This is particularly true for the Atlantic Ocean, which is affected by emissions from America, Africa and Europe. ${ }^{11,12}$ It has been extensively studied on several transects for legacy pollutants, such as polychlorinated biphenyls $(\mathrm{PCBs})^{11}$ and polycyclic aromatic hydrocarbons $(\mathrm{PAHs})^{13}$, polychlorinated dibenzo- $p$-dioxins and furans ${ }^{1}$ and hexachlorocyclohexanes ${ }^{14-16}$. Most of these transects occurred on European research vessels on their biannual migration from the Arctic to the Antarctic and vice versa. These transects typically follow the western side of the North Atlantic. Sampling on these transects was invariably affected by continental emissions off Europe and Africa, making extrapolations across the entire Atlantic Ocean difficult and fraught with uncertainties. 
More recently, results of newer contaminants, such as brominated flame retardants and

50 perfluorinated alkyl acids and sulfonates have been published. ${ }^{17-20}$ Yet we still know very

51 little about their sources, transport and fate on the ocean-scale. Our recent results suggested

52 that the remote oligotrophic Ocean has become a secondary source of PCBs ${ }^{21,22}$. Contrarily,

53 PAHs continue to deposit into the Atlantic Ocean ${ }^{23}$, possibly linked to their reactivity in the

54 surface water. ${ }^{13}$ Recent results showed the widespread presence of brominated flame 55 retardants, particularly polybrominated diphenylethers (PBDEs), at trace levels in air and water across the Atlantic Ocean. ${ }^{17,24,25}$ Air-water exchange gradients implied on-going net deposition of PBDEs into the surface waters. ${ }^{17}$

A research cruise of the $R / V$ Endeavor in July-August 2009 from Namibia via Barbados back

to her home port in Narragansett (RI), USA offered us a unique opportunity to determine

60 PBDE concentrations in air, water and air-water exchange gradients across the tropical

Atlantic Ocean (Figure 1). The cruise track covered both large east-west and north-south gradients, and was mostly far away from shore. In addition to the traditional sampling of PBDEs using active high-volume air and water sampling, we also deployed passive polyethylene (PE) samplers as complementary approaches to measure truly dissolved concentrations. Previous results suggested good agreement between active and passive sampling (e.g., within a factor of 2 for PCBs). ${ }^{21}$ In summary, we collected and analyzed samples across the tropical Atlantic to deduce whether (i) there were significant east-west and north-south gradients of selected PBDE congeners; (ii) the tropical Atlantic Ocean was a net sink or secondary source of PBDEs; and (iii) to compare active and passive sampling approaches for PBDEs; and (iv) estimate settling fluxes of PBDEs in air and water to determine the turnover of PBDEs in these compartments. 


\section{$74 \quad$ Sampling}

High volume water sampling

Active air and water sampling were taken as detailed previously. ${ }^{22}$ In brief, a total of 57 water samples were collected in the ship's laboratory from the ship's seawater pipe using a sampling train, equipped with a pre-combusted glass fiber filter (GFF) and 3 polyurethane foam (PUF) plugs in series. Water samples were collected continuously. Initially (samples 133) collected 600-1100 L of water, after Barbados, 200-500 L were filtered (samples 34- 57).

\section{High volume air samples}

Air sampling was conducted when the wind came from across the bow to collect uncontaminated marine boundary layer air. Previous work has shown that sampling of POPs can easily be contaminated from the ship's emission (either indoor air or stack emission). ${ }^{26}$ During this transect, winds often shifted away from the bow, such that only 47 air samples were collected using a high-volume air sampler, equipped with a pre-combusted GFFs and 2 pre-extracted PUF plugs. The active air sampler was set-up at the front of the monkey's level (above the bridge), facing the wind. Up to sample 23, volumes of $400-570 \mathrm{~m}^{3}(\sim 12$ hours each) were collected, after Barbados, volumes were $\sim 230-350 \mathrm{~m}^{3}$ ( $\sim 8$ hours each).

\section{PE sheet samplers}

Passive samplers were deployed to (a) the indoor air for $1-2$ weeks each ( $n=7)$; (b) the marine air for consecutive 48 hours $(n=12)$; (c) to flowing seawater in the ship's laboratory for consecutive 48 hours $(n=13)$; and (d) samplers were towed behind the ship for 48 hours outside country's exclusive economic zones (limiting these to $n=9$ ). 
The air PE samplers were exposed in inverted stainless steel bowls ('UFO disk') on the ship's main (chimney) mast $17.5 \mathrm{~m}$ above sea level (i.e., several meters above the high-volume sampler). PE samplers were exposed continuously, even when hi-volume air sampling was paused due to adverse winds. The water PE was fixed in a steel pipe connected to the flowing seawater in side the ship's special purpose laboratory, at a nominal flow rate of $10 \mathrm{~L} \mathrm{~min}^{-1}$. PE samplers were towed on a line via the A-frame, ca. $100 \mathrm{~m}$ behind the ship, for 40-70 hours each.

\section{Sample analysis}

High volume samples (PUFs, GFFs)

Analytical standards for PBDEs (calibration sets, natives and ${ }^{13} \mathrm{C}$ labeled) were purchased from Wellington Laboratories (Canada). PUFs and GFFs were extracted using automated warm Soxhlet extraction (40 minutes warm Soxhlet followed by 20 minutes of solvent rinsing) with dichloromethane (DCM) in a B-811 extraction unit (Büchi, Switzerland). The extracts of water PUF a GFF samples were first dried using $\mathrm{Na}_{2} \mathrm{SO}_{4}$, concentrated and then split into 2 portions, $1 / 4$ of extract was used for PAHs analysis, ${ }^{23}$ the remaining $3 / 4$ of extract were used for PBDEs, indicator PCBs and OCPs analysis. ${ }^{21}$

\section{Analysis}

Several ${ }^{13}$ C BDEs $(28,47,99,100,153,154,183$ and 209, all from Wellington Laboratories, Canada) were added prior to extraction. The extract was cleaned-up on a $\mathrm{H}_{2} \mathrm{SO}_{4}$ modified $(30 \% \mathrm{w} / \mathrm{w})$ silica column. Analytes were eluted with $40 \mathrm{~mL} \mathrm{DCM} / n$-hexane mixture (1:1). The eluate was concentrated using stream of nitrogen in a TurboVap II concentrator unit and transferred into an insert in a vial. The syringe standards $\left({ }^{13} \mathrm{C}\right.$ BDEs 77 and 138 and native PCB 121) were added to all samples, the final volume was $50 \mathrm{uL}$. 
122 HRGC/HRMS instrumental analysis for PBDEs was performed on 7890A GC (Agilent, USA)

123 equipped with a $15 \mathrm{~m} \times 0.25 \mathrm{~mm} \times 0.10 \mu \mathrm{m}$ DB5 column (Agilent J\&W, USA) coupled to

124 AutoSpec Premier MS (Waters, Micromass, UK). The MS was operated in EI+ mode at the

125 resolution of $>10000$. For BDE 209, the MS resolution was set to $>5000$. Injection was

126 splitless $1 \mu \mathrm{L}$ at $280^{\circ} \mathrm{C}$, with $\mathrm{He}$ as carrier gas at $1 \mathrm{~mL} \mathrm{~min}{ }^{-1}$. The $\mathrm{GC}$ temperature program

127 was $80^{\circ} \mathrm{C}$ ( 1 min hold), then $20^{\circ} \mathrm{C} \min ^{-1}$ to $250^{\circ} \mathrm{C}$, followed by $1.5^{\circ} \mathrm{C} \min ^{-1}$ to $260^{\circ} \mathrm{C}(2 \mathrm{~min}$

128 hold) and $25^{\circ} \mathrm{C} \min ^{-1}$ to $320^{\circ} \mathrm{C}$ (4.5 min hold).

$130 \quad$ PE sheet samplers

131 Blanks and exposed sheets of PE were rinsed with Millipore water, dried with a disposable

132 tissue and soaked for 24 hours in $200 \mathrm{~mL}$ of $n$-hexane followed by 24 hours in $200 \mathrm{~mL}$ of

133 DCM. The two solvents were then pooled; concentrated using stream of nitrogen in a

134 TurboVap II concentrator and the extract was split into 2 portions and processed using the

135 same procedure as the high volume samples.

136

\section{Quality assurance, Quality control}

138 The results for PBDEs in high volume samples are recovery corrected (recoveries ranged

139 from 34 to $110 \%$, Table S7). Method performance was tested prior to sample preparation.

140 Four field blanks were extracted for water and air GFFs each; Four PUF blanks were

141 extracted for air and water samples each (one PUF blank was excluded for air samples) and

142 combined for blank correction and method detection limit (MDL) determination. The MDL

143 was calculated as 3 standard deviations of blank concentrations (for more details, see SI and

144 Tables S2-S6).

145

146 Physicochemical properties 
147 Best-fit values of PE-water $\left(K_{\mathrm{PEw}}\right)$ equilibrium partition constants were taken from Lohmann

$148(2012)^{27}$, and corrected for average sampling temperature and salinity (Table S1). PE-air

$149\left(K_{\mathrm{PEa}}\right)$ values were calculated based on a linear regression of subcooled-liquid vapour pressure

$150\left(p_{\mathrm{L}}\right)$ established for PAHs, OCPs and PCBs (data not shown). Octanol-water partition constant

$151\left(K_{\mathrm{ow}}\right)$ and $p_{\mathrm{L}}$ values were calculated on the correlation with molecular weight presented by

152 Dugani and Wania (2003). ${ }^{28}$ The Setschnow constant was taken as 0.35 , as reported

153 elsewhere. ${ }^{29}$ Average values were taken for enthalpies of PE-water $\left(25 \mathrm{~kJ} \mathrm{~mol}^{-1}\right)$ and PE-air

154 exchange $\left(80 \mathrm{~kJ} \mathrm{~mol}^{-1}\right)$, close to calculated values of internal octanol-water and octanol-air

155 exchange. ${ }^{30,31}$

156

\section{Concentrations and fluxes from PE samplers}

158 Truly dissolved concentrations of PBDEs in water, $\mathrm{C}_{\text {diss }}\left(\mathrm{pg} \mathrm{L}^{-1} \mathrm{H}_{2} \mathrm{O}\right)$ and gas-phase, $\mathrm{C}_{\text {gas }}(\mathrm{pg}$

$159 \mathrm{~m}^{-3}$ ) were derived from PE-normalized concentrations, $\mathrm{C}_{\mathrm{PE}}\left(\mathrm{pg} \mathrm{L}^{-1} \mathrm{PE}\right)$ :

160

$$
\mathrm{C}_{\text {diss/gas }}=\frac{C_{P E}}{\mathrm{~K}_{\mathrm{PEw} \text { (or PEa) }} \times\left(1-\mathrm{e}^{-\frac{\mathrm{R}_{\mathrm{s}} \times \mathrm{t}}{\mathrm{K}_{\mathrm{PEw}(\text { or PEa })} \times \mathrm{V}_{\mathrm{PE}}}}\right)}
$$

161 Where $\mathrm{R}_{\mathrm{s}}\left(\mathrm{m}^{3}\right.$ day $\left.^{-1}\right)$ is the overall sampling rate, $\mathrm{t}$ is the deployment time (days), $V_{\mathrm{PE}}$ the

162 volume of the PE sampler $\left(\mathrm{m}^{3}\right)$ and $K_{\mathrm{PEw}}\left(\right.$ or $K_{\mathrm{PEa}}$ ) is corrected for the average temperature

163 and salinity of the deployment (for details, see SI). Sampling rates were estimated based on

164 PRC loss and typical uptake rates. ${ }^{21}$ For towed samplers, we assumed equilibration was

165 achieved. In view of the high molecular weights (MW) of BDEs, $\mathrm{R}_{\mathrm{s}}$ was modulated relative to

166 BDE 28 as a function of $\mathrm{MW}^{-0.4}$, representing an average of previous relationships between $\mathrm{R}_{S}$

167 and molecular size. ${ }^{32}$

168 Air-water exchange fluxes, $\mathrm{F}_{\mathrm{aw}}\left(\mathrm{pg} \mathrm{m}^{-2}\right.$ day $\left.^{-1}\right)$, were calculated according to the two-film

169 theory. The air-water exchange velocity, $\mathrm{k}_{\mathrm{ol}}\left(\mathrm{m} \mathrm{d}^{-1}\right)$, was estimated as detailed previously. ${ }^{23}$ 


$$
\mathrm{F}_{\mathrm{a} / \mathrm{w}}=C_{d i s s}-\frac{C_{g a s}}{\mathrm{~K}_{\mathrm{aw}}} \times \mathrm{k}_{\mathrm{ol}}
$$

\section{Meteorological and sea surface auxiliary measurements}

173 From the ship's routine measurements, we averaged values of latitude, longitude, surface

174 water temperature $\left(\mathrm{T}_{\text {water }}\right)$, salinity, and fluorescence of the flow-through seawater; air 175 temperature $\left(\mathrm{T}_{\text {air }}\right)$, relative humidity $(\mathrm{RH})$, relative and absolute wind speed and direction 176 recorded every minute for each sampling period (see SI). Back - trajectories were calculated

177 for 5 days with $6 \mathrm{~h}$ steps at $300 \mathrm{~m}$ above sea level using HYSPLIT. ${ }^{33}$ Concentrations of 178 dissolved organic carbon (DOC) were derived from relationships by Siegel et al. (2002), 179 mostly around $1 \mathrm{mg} \mathrm{DOC} \mathrm{L}^{-1}{ }^{34}$

\section{Cruise track}

182 On the water side, the cruise covered different major currents of the tropical Atlantic Ocean

183 (Figure 1). Currents were identified based on a combination of changes in temperature (and 184 salinity for the Amazon plume) and typical current fields ${ }^{35}$ (see Table S9). In the southern 185 hemisphere, these were the Benguela, South Equatorial and North Brazil Current. Discharges 186 from the Amazon, the North Equatorial Current and Gulf Stream affected samples in the 187 northern hemisphere. We obtained back-trajectories to confirm air mass origin. ${ }^{21}$ Initially, we 188 encountered southeasterly trade winds, moving air masses in a westerly direction towards the 189 equator. We then passed the intertropical convergence zone (ITCZ), which was situated at 190 approximately $10^{\circ} \mathrm{N}$ during our cruise. The cruise then continued in the northeasterly trade 191 winds moving air masses towards the west along the equator in the $\mathrm{NH}$. The last few samples

192 were affected by the westerlies, moving air masses eastwards across the Atlantic Ocean. 
PBDE concentrations in the water

197

198

199

\section{Particle-bound PBDE water concentrations}

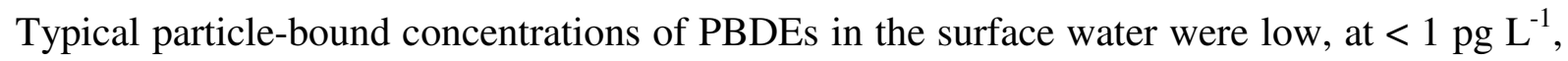
with the exception of BDE 209 (mean $7 \mathrm{pg} \mathrm{L}^{-1}$, median $1.8 \mathrm{pg} \mathrm{L}^{-1}$ ) (Table S18). The most abundant BDE congeners were 47, 99, 100 and 85, which were detected in approximately $2 / 3$ of all samples. In terms of concentrations, BDEs 47 and 99 displayed highest concentrations in most samples. When above the MDL, BDE 209 dominated overall aqueous concentrations of BDEs on particles.

A strong hemispherical gradient was apparent for particle-bound aqueous PBDEs. The ratio of the mean concentrations was approximately 5-times higher in the northern than in the southern hemisphere. For example, mean concentrations of BDEs 47 and 99 were $0.04 \mathrm{pg} \mathrm{L}^{-1}$ in the southern hemisphere, but $0.3 \mathrm{pg} \mathrm{L}^{-1}$ in the northern hemisphere. Similarly, the frequency of detection for all congeners was only $21 \%$ in the southern hemisphere, but $49 \%$ in the northern hemisphere. Clearly, the southern tropical Atlantic Ocean is much cleaner (on average 5-times) with respect to particle-bound PBDEs in the surface water than the northern hemisphere tropical Atlantic. We note that the increase in particle-bound PBDEs began at 5 $10^{\circ} \mathrm{N}$, not the equator itself (Table S18). This was probably the result of the ITCZ having shifted northwards during the northern summer, as reflected in the back-trajectories. This also implies that particle-bound PBDEs reflected fairly recent deposition events.

A closer look at the spatial distribution of particle-bound PBDEs showed that highest concentrations were detected in the Amazon plume, the Gulf Stream Eddy and in the sample closest to the U.S. coast (Figure 2). BDE 209 was only detected in a few samples from the 
218 Amazon River plume, where concentrations reached $36 \mathrm{pg} \mathrm{L}^{-1}$. In the sample taken in the Gulf

219 Stream, particle-bound BDE congener concentrations were not elevated (Figure 2).

220 Xie et al. (2011) published dissolved and particle-bound concentrations of PBDEs along a

221 North-South transect of the Eastern Atlantic Ocean in 2008. ${ }^{17}$ Particle bound BDE

222 concentrations were $\leq 0.1 \mathrm{pg} \mathrm{L}^{-1}$ (BDE 209 was not analyzed). Highest concentrations were 223 observed close to Europe and off South Africa. Particle-bound concentrations of both cruises 224 were similar in magnitude, implying that contamination-free sampling of particles was 225 achieved on both cruises.

\section{Truly dissolved PBDE concentrations from passive sampling}

228 PBDEs were detected in the towed passive samplers deployed in the water, likely due to their 229 extremely high $\mathrm{K}_{\mathrm{PEw}}$ values (causing strong enrichment in the polyethylene films) (see SI). 230 Total mass of PBDEs accumulated in the towed PE samplers were at least 10 times higher 231 than those in the flow-through water exposed PE samplers, highlighting the boundary-layer 232 limitations we encountered in the laboratory. This was also evident in the detection frequency 233 of PBDEs in both types of deployments. Whereas almost all PBDE congeners were regularly 234 detected in the towed passive sampler (overall detection frequency was 90\%, except BDE 66, 235 which was never $>$ MDL), only $<5 \%$ of PBDEs were $>$ MDL in the flow-through passive 236 sampler exposure. Towing of passive samplers could be a potentially transformative way of 237 sampling truly dissolved concentrations in the open Oceans. ${ }^{36}$ Concentrations of PBDEs were 238 greater by a factor of approximately 2 in the northern and western tropical Atlantic compared 239 to the southern and eastern section based on the towed passive sampler results.

240 The dominant congeners were BDEs 47 and 99 (Figure 3). Typical concentrations in the 241 towed $\mathrm{PE}$ were $\sim 0.5 \mathrm{pg} \mathrm{L}^{-1}$ for BDE 47 and around $0.1 \mathrm{pg} \mathrm{L}^{-1}$ for BDEs 28,99 and 100 242 (Table S12). Overall, the PE-derived concentrations were remarkably similar to those reported 
by Xie et al. (2011) for the Eastern Atlantic Ocean on a $R / V$ Polarstern cruise in 2008 (Figure

$2443) .{ }^{17}$ On that cruise, samples were taken with a classical active sampling train using PAD

245 resins and GFFs. Mean values reported by Xie et al. (2011) were $0.1 \mathrm{pg} \mathrm{L}^{-1}$ for BDEs 47 and 246 99, and a factor of 10 lower for other PBDEs (BDE 209 was not analyzed). ${ }^{17}$

247 BDE concentrations started to diverge for the highest molecular weight BDE congeners 248 (Figure 3), with PBDE concentrations from towed PE samplers suggesting much lower truly 249 dissolved concentrations than those from Xie et al. (2011)'s active sampling. ${ }^{17}$ This could be 250 due to the assumption of all PBDEs having reached equilibrium between the water and the 251 samplers during the 2-day tows. The good agreement between both types of sampling and 252 cruises ( factor of 2 ) for congeners with up to five bromines (BDE 100) suggests that 253 compounds with a $\log \mathrm{K}_{\mathrm{ow}} \leq 7$ had equilibrated. For congeners with six or more bromines, a 254 correction for non-equilibrium could be necessary, or a longer deployment time (reducing the 255 boundary layer through faster passive sampler movement seems unlikely to be achieved in the 256 field, unless through special design features). Alternatively, active sampling results could be 257 biased high due to the co-sampling of PBDEs bound to DOC.

\section{Dissolved PBDE concentrations from active sampling}

260 Dissolved concentrations from active sampling were, by and large, 8 times lower in the South 261 Atlantic than in the North Atlantic (Table S16). The dominant PBDE congeners across all 262 samples were 99, 47 and 85. In the South Atlantic, concentrations ranged from below MDL in 263 most samples towards $90 \mathrm{pg} \mathrm{L}^{-1}$ for PBDE 99. In the North Atlantic, concentrations increased 264 markedly in the Amazon River plume, where several PBDE congeners reached hundreds of $265 \mathrm{pg} \mathrm{L} \mathrm{L}^{-1}$. Two other regions of elevated concentrations were in the Gulf Stream Eddy, and the 266 sample closest to the US coast, where BDEs 47 and 99 reached several thousands $\operatorname{pg~L}^{-1}$. 267 These concentrations are far greater than reported by Xie et al $(2011)^{17}$, and the 
concentrations deduced from our towed passive samplers (both below $1 \mathrm{pg} \mathrm{L}^{-1}$ ). In fact, the concentrations from active sampling on this cruise exceeded those reported for coastal environments or Lake Michigan: dissolved $\Sigma$ PBDEs of up to $60 \mathrm{pg} \mathrm{L}^{-1}$ were reported in the coastal waters of Hong Kong ${ }^{37}, 100-200 \mathrm{pg} \mathrm{L}^{-1}$ for Izmir Bay ${ }^{38}$, while Streets et al. (2006) reported average concentration of $\Sigma$ PBDEs of $18 \mathrm{pg} \mathrm{L}^{-1}$ for Lake Michigan ${ }^{39}$.

The strong discrepancy between the dissolved PBDE concentrations reported by Xie et al. $(2011)^{17}$ and our BDE concentrations from passive sampling with our results from active sampling is reason for concern. Apparently dissolved PBDE concentrations from active sampling on our study were elevated by $10-1,000$ fold. We examined whether the collection of colloids or microplastics in our PUF-based sampling approach could explain the difference. We assumed $1 \mathrm{mg}$ DOC $\mathrm{L}^{-1}$ during the cruise. DOC-water partition constants, $\mathrm{K}_{\mathrm{DOC}}$, were taken either from Burkhard (2000) ${ }^{40}$ for natural colloids, or values extrapolated from sediment partitioning experiments by Wang et al. $(2011)^{41}$. In either case only up to $50 \%$ of the congeners dominating total dissolved concentrations (BDEs 47, 100 and 99) were bound to colloids. The subtropical gyres in the Atlantic Ocean are known to accumulate small pieces of plastic debris, or microplastics. ${ }^{42}$ If half of the [DOC] consisted of microplastics with sorption properties similar to $\mathrm{PE}$, around $50 \%$ of BDE 47 would be colloidal-bound, and $80 \%$ of BDEs 99 and 100. These calculations imply that co-sampling of colloids or microplastics cannot explain the observed active sampling results. Most likely, active sampling results became contaminated before, during or after sampling.

\section{PBDE concentrations in the atmosphere}

\section{Particle-bound PBDEs in the atmosphere}

A wide range of PBDEs were routinely detected on particles in the marine boundary layer, including BDEs 66, 100, 99, 154, 153 and 183, and often BDE 209 (Figure 4). When 
293

detected, BDE 209 dominated overall concentrations (median $1.2 \mathrm{pg} \mathrm{m}^{-3}$ ), followed by BDE $99\left(0.13 \mathrm{pg} \mathrm{m}^{-3}\right)$. For all other BDEs, mean and median concentrations were $<0.1 \mathrm{pg} \mathrm{m}^{-3}$. There were no significant differences between BDE concentrations on particles between both hemispheres (Table S10).

Concentrations were slightly greater than those reported by Xie et al. (2011) across the Eastern Atlantic Ocean (BDE 209 was not measured in that study). ${ }^{17}$ During their cruise, only BDE 47 had a median concentration greater $0.1 \mathrm{pg} \mathrm{m}^{-3}$, with other congeners mostly below detection limits. ${ }^{17}$

\section{True gas-phase PBDE concentrations from passive sampling}

Most PBDEs were detected routinely in the air passive samplers (Table S14). Greatest concentrations were obtained for BDE 47 at $1-8 \mathrm{pg} \mathrm{m}^{-3}$, followed by BDE $99\left(\leq 4 \mathrm{pg} \mathrm{m}^{-3}\right)$, with the other BDEs $<1 \mathrm{pg} \mathrm{m}^{-3}$ (Figure 4). The intermittent detection of BDE 209, ranging from $<$ MDL - $260 \mathrm{pg} \mathrm{m}^{-3}$, could be due to its episodic transport, or reflect contamination onboard. There was no significant difference between the two hemispheres in terms of gas-phase PBDE concentrations. These concentrations are comparable to, or slightly higher than those reported by Xie et al. (2011) for gas-phase PBDEs across the Eastern Atlantic (Figure 4). ${ }^{17} \mathrm{Li}$ et al. (2011) published combined gas+particle phase concentrations across the south-eastern Atlantic Ocean. ${ }^{43}$ Mean concentrations were a few $\mathrm{pg} \mathrm{m}^{-3}$, similar to the concentrations reported here.

\section{Gas-phase PBDE concentrations from active sampling}

In the southern hemisphere air samples, gas-phase PBDEs were routinely below detection limits (on the order of $1 \mathrm{pg} \mathrm{m}^{-3}$ for most congeners, see Tables S16). In several southern hemisphere samples, all PBDE congeners were detected, with concentrations reaching $1 \mathrm{ng} \mathrm{m}^{-}$ 
$318{ }^{3}$ for BDEs 47 and 99 in sample NAM-AP-020. During the collection of that particular

319 sample, the high volume sampler motor was shut off for 12 hours due to adverse wind 320 conditions, but the PUFs and GFF left in place. The exceedingly elevated concentrations from 321 this sample imply ship's emission as a strong contamination source of PBDEs.

322 Concentrations of gas-phase BDEs increased in the northern hemisphere (i.e., once the ship 323 crossed the ITCZ), with most congeners being detected above MDL regularly. Typical 324 concentrations were around $100 \mathrm{pg} \mathrm{m}^{-3}$ for BDEs 47 and 99 and at or below $10 \mathrm{pg} \mathrm{m}^{-3}$ for the 325 other congeners. A strong north-to-south gradient was apparent, with ratios of mean or 326 median concentrations implying that concentrations of PBDEs were greater in the NH by 327 factors of 2-8. The comparison with the passive sampling results, and the BDE concentrations 328 reported previously by Xie et al. $(2011)^{17}$ imply that gas-phase samples were routinely 329 contaminated. $^{26}$

\section{Air concentrations inside the ship}

332 The PE samplers deployed inside the ship displayed elevated concentrations of PBDEs, 333 particularly BDE 47 at hundreds $\mathrm{pg} \mathrm{m}^{-3}$ (Table S15). Other prominent congeners were BDE 33499,28 and 100 at tens $\mathrm{pg} \mathrm{m}^{-3}$ on average. The sum BDEs averaged $600 \mathrm{pg} \mathrm{m}^{-3}$ inside the ship, comparable to other published concentrations of PBDEs in indoor air. For example, a mean

336 concentration of $940 \mathrm{pg} \mathrm{m}^{-3}$ for $\Sigma$ PBDEs was reported for indoor air in Toronto, with other

337 studies detecting $100-200 \mathrm{pg} \mathrm{m}^{-3}$ for indoor air. ${ }^{44}$ Much higher concentrations were reported 338 for air in offices in Sweden, with concentrations ranging up to 4,700 $\mathrm{pg} \mathrm{m}^{-3}$. $^{45}$

340 The ship as a major source of PBDE contamination of samples and the environment

341 There are several lines of evidence that the $R / V$ Endeavor itself was a major source of PBDEs, 342 and partially contaminated active samples taken on-board. First, the indoor air displayed 
343 elevated concentrations of a wide range of PBDEs, in-line with concentrations observed in

344 office and residential buildings on-land. ${ }^{36,37}$ Second, field PUF blanks taken during active air 345 and water sampling resulted in elevated BDE concentrations (Tables S5-S6). Third, during a 346 couple of active sampling events, the high volume sampler (hi-vol) was shut off (but the PUFs 347 left in place) when the wind was coming from the side or stern of the ship. These samples 348 displayed strongly elevated concentrations of PBDEs. Fourth, active sampling resulted in 349 much greater PBDE concentrations than passive sampling. The gas-phase PE sampler was 350 mounted several meters above the hi-vol, implying that diffusive contamination from the ship 351 did not reach the PE sampler. Fifth, there is a noticeable increase in PBDE concentrations in 352 the PE field blanks, with lowest concentrations for the atmospheric PEs (exposed to marine 353 air) at $170 \mathrm{pg}$ per sample. The PEs mounted in the ship's laboratory were accompanied by 354 field blanks containing on average 540 pg per sample, while the towed PEs accumulated on 355 average 5,300 pg per sample. Towed PEs were mounted on the back of the ship, where the 356 ship's circulated air and engine room ventilation could often be felt.

358 Pollutant gradients across the Atlantic Ocean

359 Our results suggest that the north-western tropical Atlantic carried 5-times higher 360 concentrations of PBDEs on particles, and twice as high truly dissolved concentrations than 361 the south-eastern Atlantic Ocean. Yet our atmospheric results do not show any significant 362 differences between both hemispheres and regions. Our results seem to contradict PBDE 363 concentrations reported by Xie et al. (2011), who reported higher atmospheric concentrations 364 during their northern Atlantic Ocean transect relative to the samples taken further south. ${ }^{17}$ For 365 their aqueous samples, there was no significant difference between dissolved or particle366 bound PBDE concentrations between the North and South Atlantic. ${ }^{17}$ We suggest that the 367 gradients observed on the different cruises have as much to do with the particular regions 
being crossed rather than solely reflecting on northern versus southern hemisphere. The fact

369 that we observed greater aqueous concentrations of PBDEs in NH is mostly due to our cruise transecting the remote southern tropical Atlantic (with low PBDE concentrations) but ended

371 up sampling the Amazon River, warm core, Gulf Stream, and US coastal seaboard in the

372 northern hemisphere.

373 Xie et al. (2011) sampled the atmosphere closer to Europe and Africa for most of their 374 samples taken in the northern hemisphere, but farther from shore during their southern 375 transect, which might explain the difference in atmospheric PBDE concentrations they 376 reported. $^{17}$

\section{Air-water exchange}

379 Air-water exchange gradients were calculated based on simultaneous passive sampler 380 deployments in air and water. Gradients were based on PBDE concentrations in PE (ng g ${ }^{-1}$

381 PE) at equilibrium. ${ }^{46}$ In short, passive samplers, such as the PE we used, reflect the chemical 382 activity of the BDEs in their respective matrix (air and water in our case). The ratio of those 383 BDE activities (corrected for non-equilibrium) is the activity gradient across the air-water 384 interface.

385 In the water, results from towed PE samplers were used; in the air, the equilibrium-corrected 386 PBDE concentrations from the passive sampler deployed on the ship's mast were used. In 387 approximately $50 \%$ of possible cases, PBDEs were $>$ MDL in both phases simultaneously 388 (Table S19). Net air-water exchange gradients strongly favoured deposition of PBDEs from 389 the gas-phase into the water phase. Gradients increased with increasing MW. For BDEs 28 390 and 47, net air-to-water exchange gradients ranged from 3-13. For the higher MW BDEs 85, 39199 and 100, gradients increased to be in the range 10-50, and even greater for the higher MW 
congeners. Our results are similar to the gradients by Xie et al. (2011), who reported net 393 deposition for all PBDEs along the eastern Atlantic Ocean. ${ }^{17}$

394 Air-water exchange velocities ranged from $<1$ to $36 \mathrm{~cm} \mathrm{day}^{-1}$, and decreased with increasing 395 MW (Table S22). Net gas-phase deposition fluxes ranged from 10s of $\mathrm{pg} \mathrm{m}^{-2}$ day $^{-1}$ for BDEs 39628 and 85 to around $1 \mathrm{ng} \mathrm{m}^{-2}$ day $^{-1}$ for BDE 47, 99 and 209 (Table S23). Similar values were 397 reported by Xie et al. (2011). ${ }^{17}$

398 We calculated the net annual gas-phase deposition of PBDEs, assuming these air-water 399 exchange fluxes were representative across the Atlantic Ocean. For all PBDEs reported here, 400 the gas-phase deposition flux is approximately 40 tons annually, of which $20 \mathrm{t}$ are the median 401 flux for BDE 209.

402

\section{Deposition of PBDEs across the Atlantic Ocean}

404 We calculated the deposition flux of PBDEs on particles, $F_{\text {part,dep }}\left(\mathrm{pg} \mathrm{m}^{-2}\right.$ day $\left.^{-1}\right)$, across the 405 Atlantic Ocean as:

$406 \quad \mathrm{~F}_{\text {part,dep }}=\mathrm{C}_{\text {part }} \times \mathrm{v}_{\text {dep }}$

407 where $\mathrm{C}_{\mathrm{part}}$ is the particle-bound PBDE concentration $\left(\mathrm{pg} \mathrm{m}^{-3}\right)$ from this cruise and $\mathrm{v}_{\mathrm{dep}}$ is the 408 deposition velocity taken as $0.1 \mathrm{~cm} \mathrm{~s}^{-1}$ as reported by DelVento and Dachs (2007). ${ }^{47}$ This 409 translates into a half-live of particle-bound PBDEs in a $1000 \mathrm{~m}$ marine boundary layer of 410 around 6 days. Calculated deposition fluxes were dominated by BDE 209 (median flux of 100 $411 \mathrm{pg} \mathrm{m}{ }^{-2}$ day $^{-1}$ ), BDEs 47 and 99 (median fluxes of 46 and $11 \mathrm{pg} \mathrm{m}^{-2}$ day $^{-1}$ ). These fluxes 412 compare well to those calculated by Xie et al. (2011) for PBDEs across the Eastern Atlantic 413 Ocean. $^{17}$

414 If the results reported here are representative across the Atlantic Ocean, the annual deposition 415 of particle-bound BDEs 47, 99, 100 and 85 will be around a ton scaled to the entire Atlantic 416 Ocean (surface area $\sim 75 \times 10^{6} \mathrm{~km}^{2}$ ). The fact that particle-bound PBDE concentrations from 
our cruise were similar to those by Xie et al. (2011) support that assumption. The median

418 annual deposition flux for BDE 209 is 7,500 kg for the Atlantic Ocean. The fluxes derived

419 above signal a significant annual deposition (gas-phase deposition of $\sim 40 \mathrm{t}$ and particulate-

420 bound deposition of $\sim 10 \mathrm{t}$ ) of PBDEs into the Atlantic Ocean .

421 Yet the current deposition flux of PBDEs pales in comparison to production volumes of these

422 flame retardants. The estimated cumulative use of the commercial pentaBDE mixture alone 423 was estimated to $100000 \mathrm{t}$ since $1970 .^{48}$ This indicates that more is to come, as PBDEs 424 slowly make their way from products into the environment. Relative to PCBs, the gas-phase 425 deposition fluxes of PBDEs are similar in magnitude. ${ }^{4}$ Yet the particle-bound deposition flux 426 of PBDEs to the Atlantic Ocean already exceeds that of PCBs, which was estimated to be 427 around 2.2 tons per year. ${ }^{49}$ A greater fraction of PBDEs is bound to particles, explaining the 428 derived greater importance of their particle-bound deposition relative to PCBs.

\section{Settling fluxes of PBDEs out of the mixed layer}

431 We estimated settling fluxes of PBDEs out of the mixed layer depth across the tropical 432 Atlantic Ocean. The settling flux of particulate organic carbon (POC) at $100 \mathrm{~m} \mathrm{depth,} F_{O C, 100 \text {, }}$ 433 was estimated based on its relationship with Chlorophyll $a(\mathrm{Chl} a)^{50}$ :

$$
\log \left(F_{O C, 100)}=2.09+0.81 \times \log (\operatorname{Chl} \alpha)\right.
$$

436 Resulting settling fluxes of OC at $100 \mathrm{~m}$ depth were typically $30-80 \mathrm{mg} \mathrm{m}^{-2}$ day $^{-1}$, typical 437 for the tropical oceans. ${ }^{51}$ To derive a settling rate of particles out of the mixed layer depth, we 438 estimated POC concentrations based on published 10-year averages for July as reported by 439 Stramska (2009). ${ }^{52}$ We took POC concentrations as $80 \mathrm{mg} \mathrm{m}^{-3}$ up to the equator, 40 from the 440 equator to $5^{\circ} \mathrm{N}, 30$ from 5 to $10^{\circ} \mathrm{N}, 20$ from 10 to $30^{\circ} \mathrm{N}, 30$ from 30 to $35^{\circ} \mathrm{N}$ and 80 north 441 of $45^{\circ} \mathrm{N}$. Dividing $F_{O C, 100}$ by POC concentrations yields the settling velocity ${ }^{53}$, which ranged 
442 from $0.5-2.0 \mathrm{~m} \mathrm{day}^{-1}$. Lastly, the product of settling velocity and particle-bound PBDE 443 concentrations yielded the PBDE removal flux from the surface ocean layer. This PBDE 444 export flux rarely exceeded $1 \mathrm{ng} \mathrm{m}^{-2}$ day $^{-1}$ for most congeners, except for BDE 209, which 445 reached fluxes of tens $\mathrm{ng} \mathrm{m}^{-2} \mathrm{day}^{-1}$ (Figure S3). Settling fluxes were greater in the northern 446 hemisphere than south of the equator, driven by the greater frequency of detection and 447 concentrations of PBDE in the particle-phase (see above).

\section{Comparison of PBDE fluxes}

450 We compared the fluxes of gas-phase and particle-bound PBDEs out of the atmosphere to 451 those out of the Atlantic Ocean's mixed layer depth. Net gas-phase deposition fluxes were 452 much greater than the particle-bound settling fluxes, implying additional removal from the 453 surface mixed layer, probably via photolytic and microbial degradation. ${ }^{5}$ The median values 454 of both particle-bound settling fluxes agreed surprisingly well in view of the assumptions 455 behind the settling velocities in both atmosphere and surface water (Figure 6). Settling fluxes 456 were around $50 \mathrm{pg} \mathrm{m}^{-2} \mathrm{day}^{-1}$ for BDE 47 in both atmosphere and surface water, and $<10 \mathrm{pg}$ $457 \mathrm{~m}^{-2} \mathrm{day}^{-1}$ for other congeners. For PBDEs 47 through 99, settling fluxes from the surface 458 water exceeded atmospheric deposition fluxes, while for the higher brominated congeners, 459 median settling fluxes out of the mixed layer depth (MLD) were zero due to PBDEs being < 460 MDL in the water.

\section{Residence time of particle-bound PBDE in surface water}

463 The MLD was taken from published 10-year averages for July as reported by Stramska 464 (2009). ${ }^{52}$ It ranged from $80 \mathrm{~m}$ up to the equator, $40 \mathrm{~m}$ from the equator to $20^{\circ} \mathrm{N}$, and $20 \mathrm{~m}$ 465 north of $20{ }^{\circ} \mathrm{N}$. The product of MLD and total (sum of truly dissolved + particle-bound)

466 PBDEs yielded the mass loading of PBDEs on particles $\left(\mathrm{ng} \mathrm{m}^{-2}\right)$ in the surface water. The 
467 mass loading divided by the PBDE removal flux $\left(\mathrm{ng} \mathrm{m}^{-2}\right.$ day $^{-1}$ ) gave the residence time (days) 468 of particle-bound PBDEs in the surface water of the Atlantic Ocean, assuming particle settling 469 was the only removal pathway. The tight coupling of particle-bound PBDE fluxes from 470 atmosphere and out of the mixed layer could indicate that different fates of particle-bound 471 PBDEs (settling) and those derived from gaseous diffusion, probably due to chemical and 472 biological degradation of dissolved molecules in the water column. In the northern 473 hemisphere, median PBDEs' residence were several weeks, but were around one year in the 474 southern hemisphere (Figure S5). These values suggest that settling on particles is an 475 important removal pathway in the northern hemisphere, whereas biological and photolytic 476 degradation are probably determining the fate of PBDEs in the southern hemisphere.

\section{Implications}

479 Our results imply that PBDEs continue to be deposited across the Atlantic Ocean. Our 480 research vessel proved to be a significant source of contamination for PBDEs itself during 481 active sampling of air and water. Yet the use of passive samplers enabled us to retrieve valid 482 samples for both gas-phase and truly dissolved PBDEs. Other researchers have shown that 483 other contamination-free sampling can be achieved, though on a different research vessels. ${ }^{17,43}$ Our results suggest that atmospheric deposition of particle-bound PBDEs is probably slightly lower but similar in magnitude to their removal flux on settling particles from the surface mixed layer. Net gas-phase deposition of PBDEs exceeded particle-bound deposition,

487 suggesting that there are other important removal pathways for dissolved BDEs, such as 488 microbial and photolyic degradation. The total deposition of PBDEs to the Atlantic Ocean, 489 around tens of tons per year, pales in comparison to their historical production volumes. This 490 might indicate the less efficient long-range transport of these higher molecular weight 491 compounds, compared to, for example, polychlorinated biphenyls. It could also indicate that 
PBDEs are only slowly emitted from their current use, guaranteeing continuous fluxes into

493 the oceans in the future. ${ }^{54}$

494

495

Supporting Information Available

496

497

498

499

500

501

502

503

504

505

The Supporting information includes additional details, such as physicochemical constants, instrumental analysis and QC, sampling set-up and sample details, air and water concentrations. This material is available free of charge via the Internet at http://pubs.acs.org.

\section{ACKNOWLEDGMENTS}

Thanks to officers, crew and marine technician of $R / V$ Endeavor for their support; the RI Endeavor Program (RIEP) for financial support and Dr Igor Belkin (URI) for help with Figure 1. This research has been supported by the RECETOX research infrastructure (project of the Ministry of Education of the Czech Republic LM2011028) and the CETOCOEN project of the European Structural Funds (CZ.1.05/2.1.00/01.001).

\section{References}

(1) Nizzetto, L.; Lohmann, R.; Gioia, R.; Dachs, J.; Jones, K. C. Atlantic Ocean surface waters buffer declining atmospheric concentrations of persistent organic pollutants Environ Sci Technol 2010, 44, 6978-6984.

(2) Iwata, H.; Tanabe, S.; Sakai, N.; Tatsukawa, R. Distribution of Persistent Organochlorines in the Oceanic Air and Surface Seawater and the Role of Oceans on Their Global Transport and Fate Environ. Sci. Technol. 1993, 27, 1080-1098.

(3) Lohmann, R.; Jurado, E.; Pilson, M. E. Q.; Dachs, J. In Geophysical Research Letters, 2006; Vol. 33, pp L12607, 12604 PP, doi:12610.11029/12006GL025953.

(4) Dachs, J.; Lohmann, R.; Ockenden, W. A.; Mejanelle, L.; Eisenreich, S. J.; Jones, K. C. Oceanic biogeochemical controls on global dynamics of persistent organic pollutants Environmental Science \& Technology 2002, 36, 4229-4237.

(5) Galban-Malagon, C.; Berrojalbiz, N.; Ojeda, M.-J.; Dachs, J. The oceanic biological pump modulates the atmospheric transport of persistent organic pollutants to the Arctic Nat Commun 2012, 3, 862.

(6) Lohmann, R.; Jurado, E.; Dijkstra, H. A.; Dachs, J. Vertical eddy diffusion as a key mechanism for removing perfluorooctanoic acid (PFOA) from the global surface oceans Environmental Pollution 2013, 179, 88-94.

(7) Galb $\tilde{A}_{i n-M a l a g} \tilde{A}^{3} n$, C. b. J.; Del Vento, S.; Berrojalbiz, N.; Ojeda, M.-J.; Dachs, J. Polychlorinated Biphenyls, Hexachlorocyclohexanes and Hexachlorobenzene in Seawater and 
Phytoplankton from the Southern Ocean (Weddell, South Scotia, and Bellingshausen Seas)

530 Environmental Science \& Technology 2013, 47, 5578-5587.

531 (8) Schwarzenbach, R. P.; Gschwend, P. M.; Imboden, D. M. Environmental Organic

532 Chemistry; 2nd ed.; Wiley-Interscience: New Jersey, 2003.

533 (9) Latch, D. E.; Packer, J. L.; Arnold, W. A.; McNeill, K. Photochemical conversion of 534 triclosan to 2,8-dichlorodibenzo-p-dioxin in aqueous solution Journal of Photochemistry and 535 Photobiology a-Chemistry 2003, 158, 63-66.

536 (10) Schenker, U.; Soltermann, F.; Scheringer, M.; Hungerbühler, K. Modeling the Environmental Fate of Polybrominated Diphenyl Ethers (PBDEs): The Importance of Photolysis for the Formation of Lighter PBDEs Environ Sci Technol 2008, 42, 9244-9249. (11) Gioia, R.; Eckhardt, S.; Breivik, K.; Jaward, F. M.; Prieto, A.; Nizzetto, L.; Jones, K. 
(24) Moller, A.; Xie, Z. Y.; Sturm, R.; Ebinghaus, R. Polybrominated diphenyl ethers (PBDEs) and alternative brominated flame retardants in air and seawater of the European Arctic Environmental Pollution, 159, 1577-1583. (25) Moller, A.; Xie, Z. Y.; Sturm, R.; Ebinghaus, R. Large-Scale Distribution of Technology, 44, 8977-8982.

(26) Lohmann, R.; Jaward, F. M.; Durham, L.; Barber, J. L.; Ockenden, W.; Jones, K. C.; Bruhn, R.; Lakaschus, S.; Dachs, J.; Booij, K. Potential contamination of shipboard air samples by diffusive emissions of PCBs and other organic pollutants: Implications and solutions Environmental Science \& Technology 2004, 38, 3965-3970.

(27) Lohmann, R. A critical review of low-density polyethylene's partitioning and diffusion coefficients for trace organic contaminants and implications for its use as a passive sampler Environ Sci Technol 2012, 36, 606-618, DOI: 610.1021/es202702y.

(28) Wania, F.; Dugani, C. Assessing the long-range transport potential of polybrominated diphenyl ethers: A comparison of four multimedia models Environmental Toxicology and Chemistry 2003, 22, 1252-1261.

(29) Jonker, M. T. O.; Muijs, B. Using solid phase micro extraction to determine saltingout (Setschenow) constants for hydrophobic organic chemicals Chemosphere 2010, 80, 223227.

(30) Beyer, A.; Wania, F.; Gouin, T.; Mackay, D.; Matthies, M. Selecting internally consistent physicochemical properties of organic compounds Environmental Toxicology and Chemistry 2002, 21, 941-953.

(31) Schenker, U.; MacLeod, M.; Scheringer, M.; Hungerbuhler, K. Improving data quality for environmental fate models: A least-squares adjustment procedure for harmonizing physicochemical properties of organic compounds Environ. Sci. Technol. 2005, 39, 84348441.

(32) Lohmann, R.; Booij, K.; Smedes, F.; Vrana, B. Use of passive sampling devices for monitoring and compliance checking of POP concentrations in water Environmental Science and Pollution Research 2012, 19, 1885-1895.

(33) NOAA: http://www.arl.noaa.gov.

(34) Siegel, D. A.; Maritorena, S.; Nelson, N. B.; Hansell, D. A.; Lorenzi-Kayser, M. Global distribution and dynamics of colored dissolved and detrital organic materials Journal of Geophysical Research-Oceans 2002, 107, 14.

(35) Gyory, J.; Mariano, A. J.; Ryan., E. H., 2001-2013; Vol. 2013.

(36) Allan, I. J.; Harman, C. Global Aquatic Passive Sampling: Maximizing Available Resources Using a Novel Exposure Procedure Environmental Science \& Technology 2011, 45, 6233-6234.

(37) Wurl, O.; Lam, P. K. S.; Obbard, J. P. Occurrence and distribution of polybrominated diphenyl ethers (PBDEs) in the dissolved and suspended phases of the sea-surface microlayer and seawater in Hong Kong, China Chemosphere 2006, 65, 1660-1666.

(38) Cetin, B.; Odabasi, M. Air-water exchange and dry deposition of polybrominated diphenyl ethers at a coastal site in Izmir Bay, Turkey Environmental Science \& Technology 2007, 41, 785-791.

(39) Streets, S. S.; Henderson, S. A.; Stoner, A. D.; Carlson, D. L.; Simcik, M. F.; Swackhamer, D. L. Partitioning and Bioaccumlation of PBDEs and PCBs in Lake Michigan Environ Sci Technol 2006, 40, 7263-7269.

(40) Burkhard, L. P. Estimating dissolved organic carbon partition coefficients for nonionic organic chemicals Environmental Science \& Technology 2000, 34, 4663-4668.

(41) Wei Wang; Delgado-Moreno, L.; Ye, Q.; Gan, J. Improved Measurements of Partition Coefficients for Polybrominated Diphenyl Ethers Environ Sci Technol 2011, 45, 1521-1527. 
(42) Kara Lavender Law; Skye Morét-Ferguson; Nikolai A. Maximenko; Giora

629 Proskurowski; Emily E. Peacock; Jan Hafner; Reddy, C. M. Plastic Accumulation in the

630 North Atlantic Subtropical Gyre Science 2010, 329, 1185-1188.

631 (43) Li, J.; Li, Q. L.; Gioia, R.; Zhang, Y. L.; Zhang, G.; Li, X. D.; Spiro, B.; Bhatia, R. S.;

632 Jones, K. C. PBDEs in the atmosphere over the Asian marginal seas, and the Indian and

633 Atlantic oceans Atmospheric Environment 2011, 45, 6622-6628.

634 (44) Zhang, X.; Diamond, M.; Robson, M.; Harrad, S. Sources, Emissions, and Fate of

635 Polybrominated Diphenyl Ethers and Polychlorinated Biphenyls Indoors in Toronto, Canada

636 Environ Sci Technol 2011, 45, 3268-3274.

637 (45) Bjorklund, J. A.; Thuresson, K.; Cousins, A. P.; Sellstrom, U.; Emenius, G.; de Wit, C.

638 Indoor Air Is a Significant Source of Tri-decabrominated Diphenyl Ethers to Outdoor Air via

639 Ventilation Systems Environ Sci Technol 2012, 46, 5876-5884.

640 (46) Morgan, E.; Lohmann, R. Detecting Air-Water and Surface-Deep Water Gradients of

641 PCBs Using Polyethylene Passive Samplers Environ Sci Technol. 2008, 7248-7253.

642 (47) Del Vento, S.; Dachs, J. Atmospheric occurrence and deposition of polycyclic

643 aromatic hydrocarbons in the northeast tropical and subtropical Atlantic Ocean Environmental

644 Science \& Technology 2007, 41, 5608-5613.

645 (48) UNEP "Report of the Persistant Organic Pollutants Review committee on the work of 646 its third meeting - addendum, Risk management evaluation on commercial

647 pentabromodiphenylether," 2007.

648 (49) Jurado, E.; Jaward, F. M.; Lohmann, R.; Jones, K. C.; Simo, R.; Dachs, J.

649 Atmospheric dry deposition of persistent organic pollutants to the Atlantic and inferences for

650 the global oceans Environmental Science \& Technology 2004, 38, 5505-5513.

651 (50) Baines, S. B.; Pace, M. L. Why does the relationshop between sinking flux and

652 planktonic primary production differ between lakes and oceans? Limnology Oceanography

653 1994, 39, 213-226.

654 (51) Henson, S. A.; Sanders, R.; Madsen, E. Global patterns in efficiency of particulate

655 organic carbon export and transfer to the deep ocean Global Biogeochemical Cycles 2012, 26.

656 (52) Stramska, M. Particulate organic carbon in the global ocean derived from SeaWiFS

657 ocean color Deep-Sea Res. Part I-Oceanogr. Res. Pap. 2009, 56, 1459-1470.

658 (53) Lohmann, R.; Dachs, J. Deposition of Dissolved and Particulate-Bound Chemicals

659 from the Surface Ocean. In Handbook of Chemical Mass Transport in the Environment;

660 Thibodeaux, L. J., Mackay, D., Eds.; CRC Press: Boca Raton, FL, 2011; p 631.

661 (54) Harrad, S.; Diamond, M. L. New Directions: Exposure to polybrominated diphenyl

662 ethers (PBDEs) and polychlorinated biphenyls (PCBs): Current and future scenarios

663 Atmospheric Environment 2006, 40, 1187-1188.

664 (55) Feldman, G. C.; NASA Goddard Space Flight Center, 2013.

665 
666

667

668

669

670

671
Figure 1: Cruise track of EN 464 with chlorophyll a concentrations derived from MODIS ${ }^{55}$

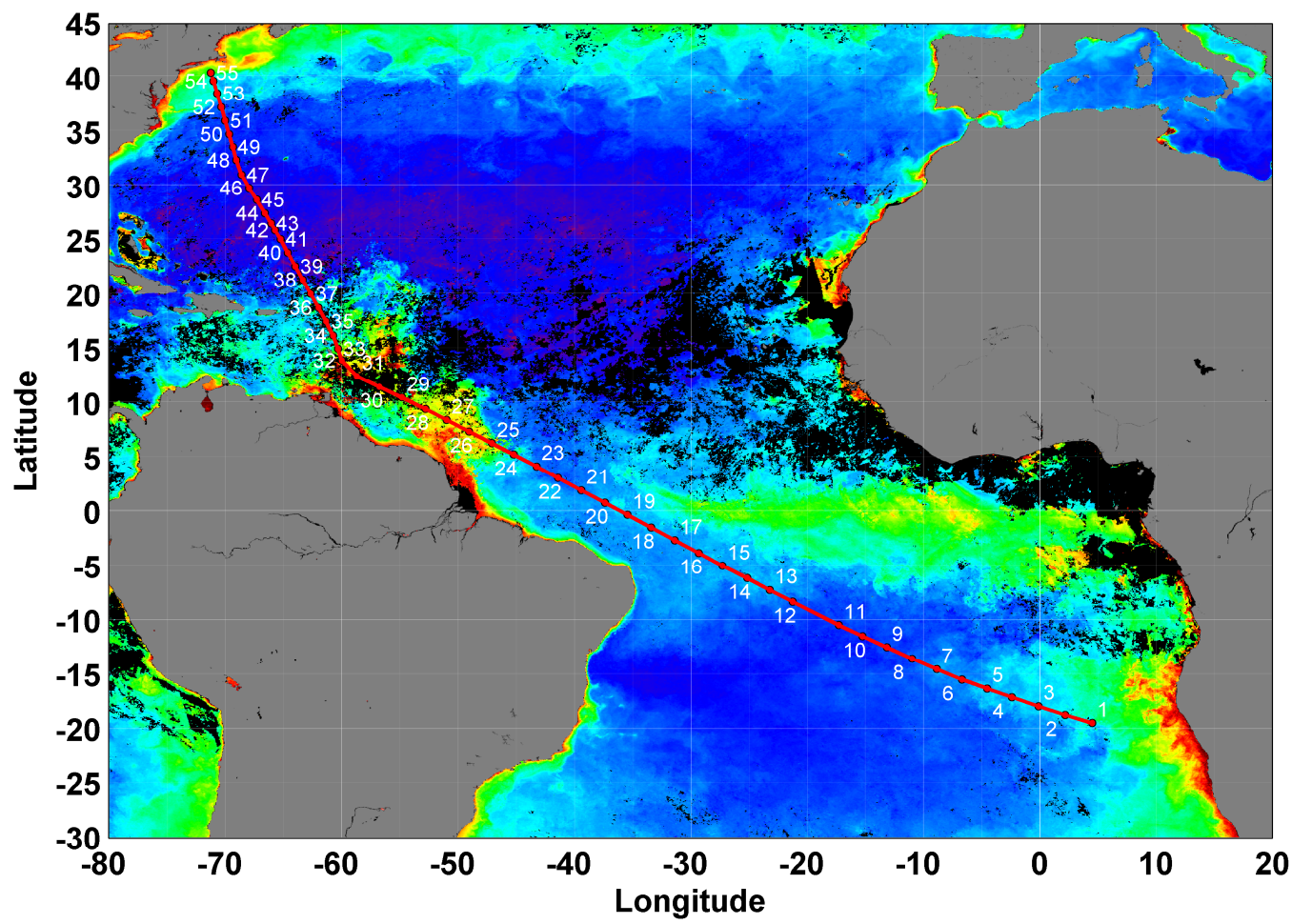


672 Figure 2: Concentrations of aqueous particle-bound PBDE congeners $\left(\mathrm{pg} \mathrm{L}^{-1}\right)$ in 2009

673

674

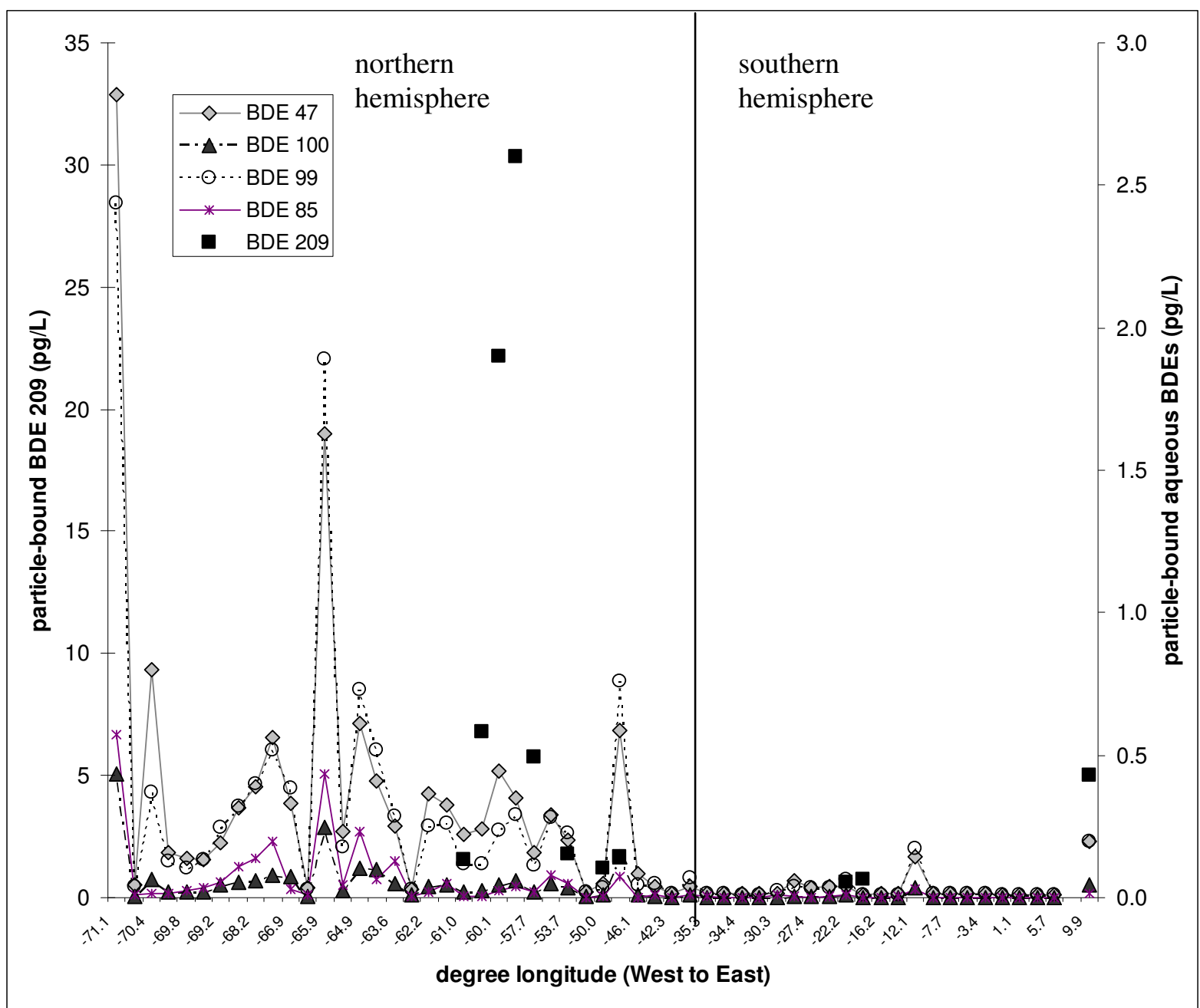

675

676

Note: concentrations of BDE 209 are displayed on right-hand side 
677 Figure 3: Dissolved concentrations of PBDE congeners derived from towed passive PE 678 samplers (pg $\mathrm{L}^{-1}$ ) across the tropical Atlantic Ocean in 2009. Displayed are average 679 concentrations for the southern and northern hemisphere, and mean and median results 680 from Xie et al. (2011) ${ }^{17}$ for comparison.

681

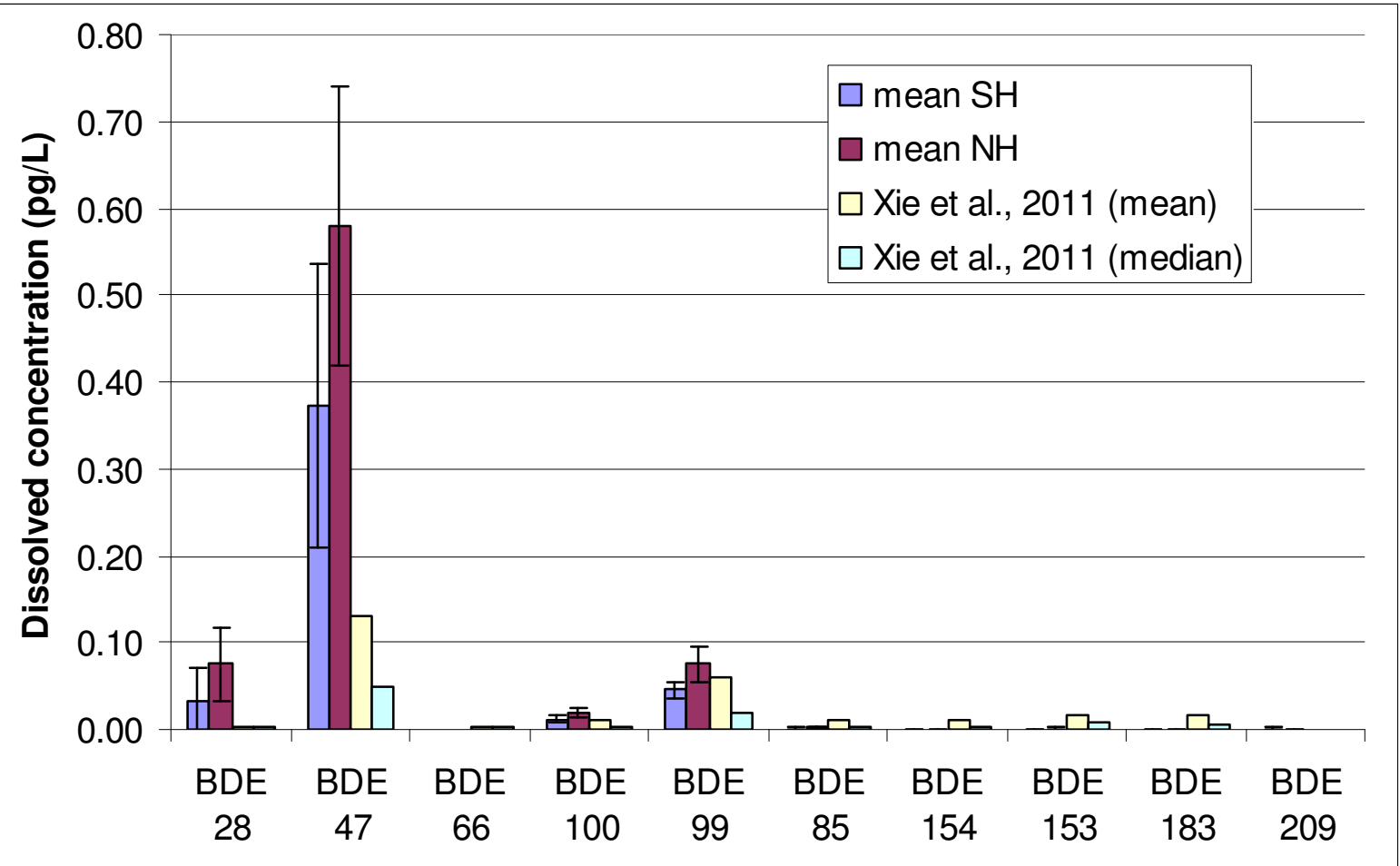


685 Figure 4: Particle-bound atmospheric concentrations of PBDE congeners $\left(\mathrm{pg} \mathrm{m}^{-3}\right)$ in

686 2009

687

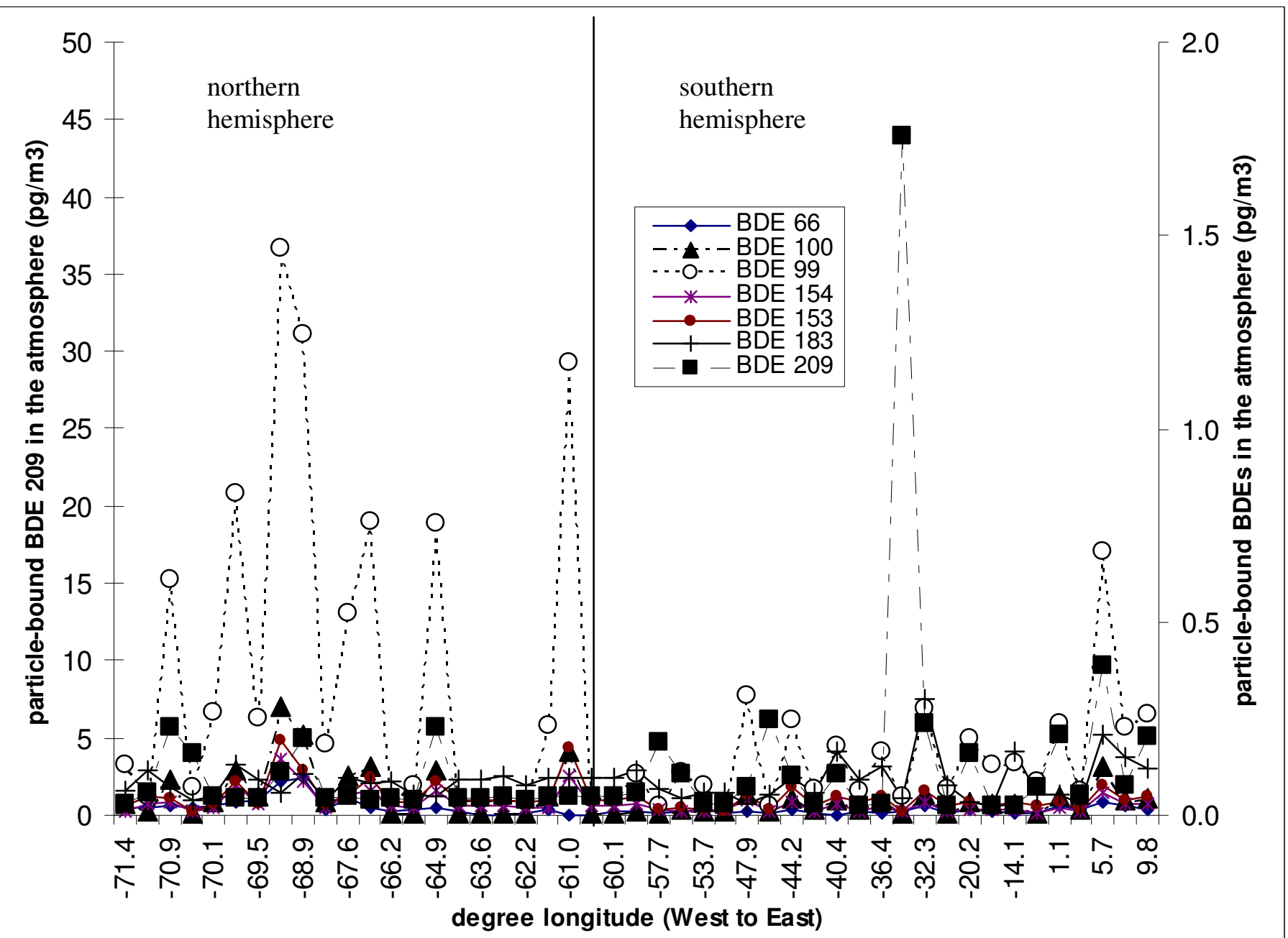

690

Note: concentrations of BDE 209 are displayed on right-hand side

691 
692 Figure 5: Gas-phase atmospheric concentrations of PBDE congeners derived from 693 passive PE samplers $\left(\mathrm{pg} \mathrm{m}^{-3}\right.$ ) across the tropical Atlantic Ocean in 2009. Displayed are 694 average concentrations for the southern and northern hemisphere, and mean and median results from Xie et al. (2011) ${ }^{17}$ for comparison.

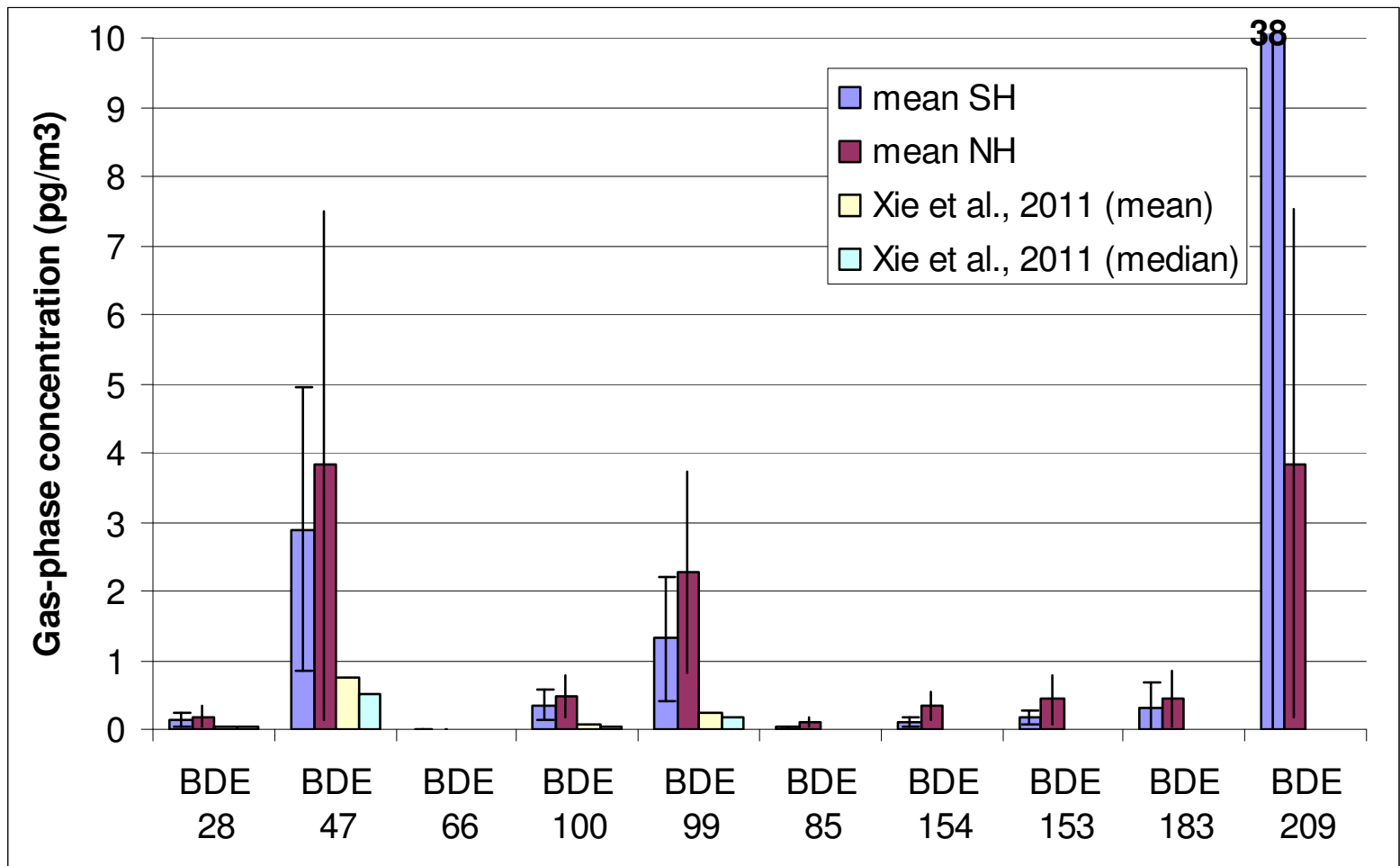


703 Figure 6: Comparison of median fluxes for PBDEs $\left(\mathrm{pg} \mathrm{m}^{-2} \mathbf{d a y}^{-1}\right)$ from net gas-phase and particle-bound deposition out of the atmosphere and via particle-bound settling out of the mixed layer depth

706

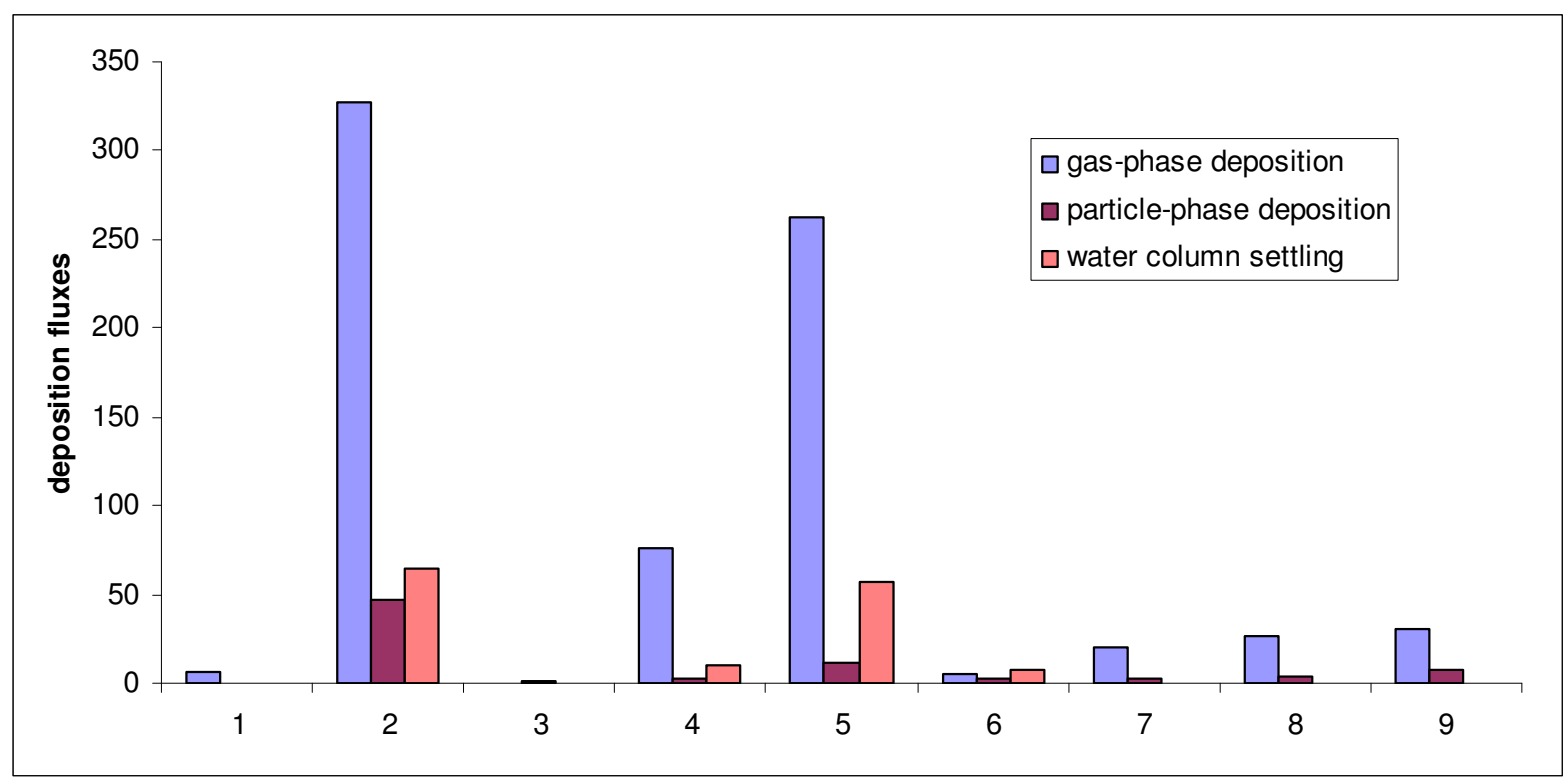




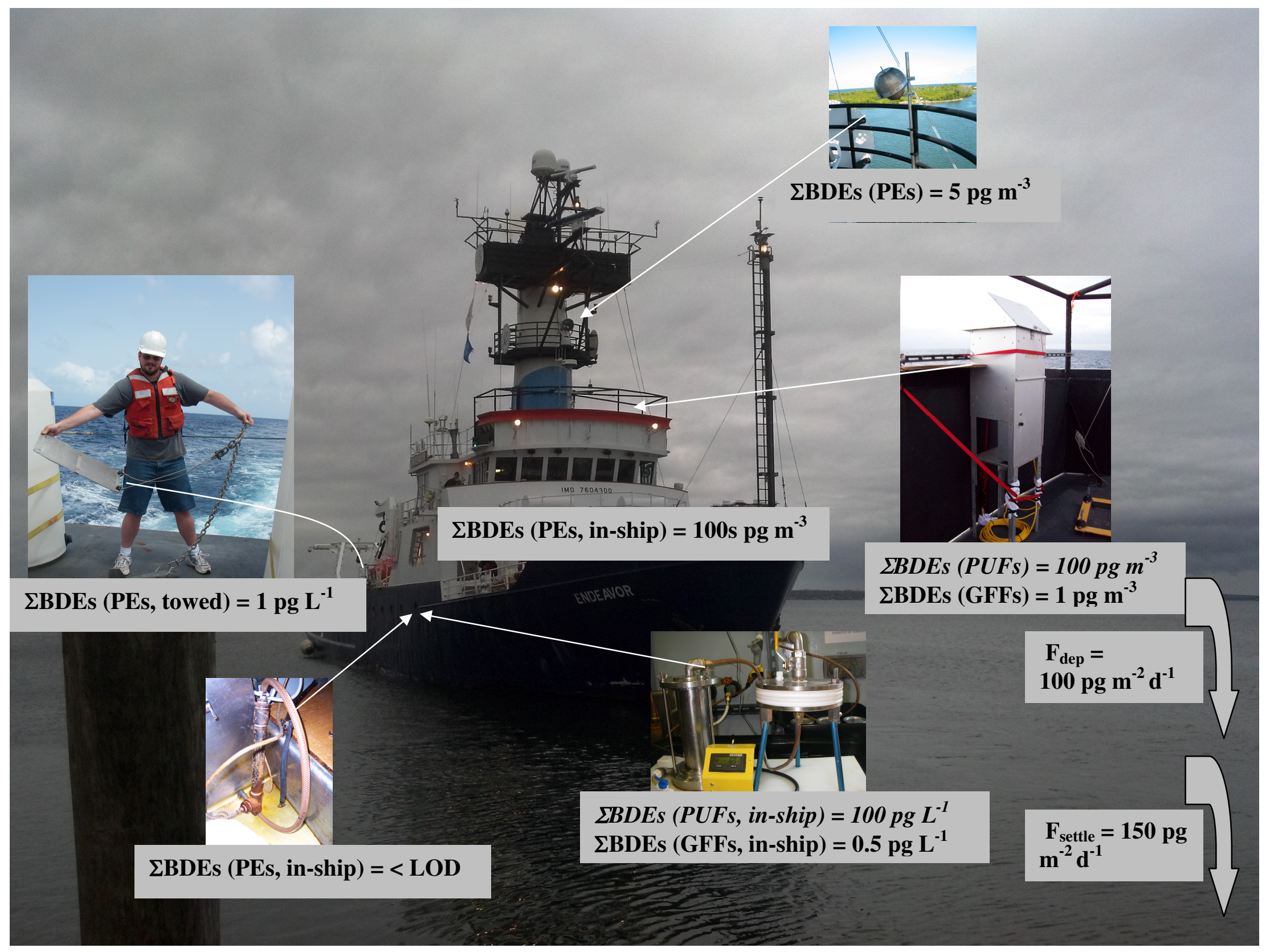

